\title{
NATURAL FREQUENCY ANALYSIS OF LAYERED FUNCTIONALLY GRADED BEAMS
}

\author{
Savaş EVRAN * \\ Machine and Metal Technologies Department, Çanakkale Technical Sciences Vocational School, \\ Çanakkale Onsekiz Mart University, Çanakkale, Turkey
}

\begin{abstract}
In this numerical study, natural frequency analysis of the layered functionally graded beams in the thickness direction for clamped-clamped and clamped-free boundary conditions was investigated using finite element software ANSYS and the effects of the layers on natural frequency analysis for first mode were evaluated under clamped-free boundary condition. The layer arrangements of the beams were performed according to Taguchi L9 (3x3) orthogonal array. Mechanical properties of the layers made of different volume fractions of Ti-6Al-4V and $\mathrm{ZrO}_{2}$ materials was assumed as control factors. In order to determine the optimum layers and their levels, signal-to-noise $(\mathrm{S} / \mathrm{N})$ ratio analysis was used. Significant layers and their percent contributions on the first mode natural frequency were carried out using Analysis of Variance (ANOVA). In addition, the effects of the boundary conditions (B.C.) such as clamped-free (C-F) and clamped-clamped (C-C) and positions of the optimum layers were evaluated. According to results observed, maximum first mode natural frequency for C-F boundary condition using optimum layers were found using the FG beams with top and bottom layers with ceramic-rich and middle layer with metalrich. The most effective layers on the responses was obtained as L1 with $48.4523 \%$, L2 with $16.1547 \%$ and L3 with $34.9839 \%$. Layer arrangements for C-F boundary condition play important role on the natural first mode frequency.
\end{abstract}

Keywords: Functionally graded materials, Natural frequency, Beam, Finite element method

\section{INTRODUCTION}

In the Sendai area, Japan, Functionally Graded Materials (FGMs) were presented by scientists working in material science as a means of designing thermal barrier materials in 1984 [1]. After that year, these materials have been used for various application fields such as nuclear energy [2] army [3], sensor and energy [4], biomedical [5], tool materials [6], thermal barrier coating [7] and rotating blades [8] etc. In the following years, many studies for different areas are published using this concept (FGMs). In the literature, Lee and Lee [9] observed the free vibration behavior of Bernoulli-Euler beams consisting of FGM under different boundary conditions according to exact transfer matrix technique. Sina et al. [10] presented a research about free vibration behavior of the beams formed using functionally graded materials based on an analytical method. Giunta et al. [11] evaluated the free vibration behavior of the beams consisting of FGM according to hierarchical theories. Şimşek [12] observed the free vibration characteristics of beams prepared using FGM under different boundary conditions according to different higher-order beam theories. Aydogdu and Taskin [13] observed the free vibration behavior of beams formed using FGM according to simply supported edges. Kahya and Turan [14] performed a study consisting of a finite element model according to the first-order shear deformation theory for buckling and free vibration behaviors of the beams consisting of functionally graded materials. Thai and Vo [15] investigated the free vibration and bending behaviors of the beams consisting of FGM and they used different higher-order shear deformation beam theories for analyses. Alshorbagy et al. [16] evaluated the numerical free vibration behavior of the beam designed using FGM according to finite element method. Nguyen et al. [17] published a study including the free vibration and static behaviors of rectangular beams consisting of FGM under axially loading according to first-order shear deformation theory. Kapuria et al. [18] performed a study consisting of bending and free vibration analyses of layered 
beams with FGM in thickness direction experimentally and theoretically. Li et al. [19] carried out a work including the bending, buckling and vibration behaviors of beams consisting of FGM in the axial direction according to nonlocal strain gradient theory. Huang et al. [20] investigated the free vibration behavior Timoshenko beams consisting of FGM in the axial direction and it was assumed that beams have non-uniform cross-section. Shahba and Rajasekaran [21] analyzed the free vibration and stability characteristics of tapered Bernoulli-Euler beams consisting of functionally graded materials in the axial direction. Wattanasakulpong and Ungbhakorn [22] carried out the free vibration behavior of beams with FGM under general elastically end constraints and they used differential transformation method to carry out the analysis. Demir and Oz [23] observed the free vibration behavior of the beam prepared using functionally graded materials under various boundary conditions and they used finite element method to perform the analysis. Demir and Oz [24] observed the free vibration characteristics of the viscoelasticsupported beam made of functionally graded materials. Anandrao et al. [25] analyzed the free vibration behavior of the beams consisting of FGM under different classical boundary conditions. Kukla and Rychlewska [26] carried out the free vibration characteristics of the beams created using FGM in the axial direction. Koochaki [27] performed a study consisting of an exact analytical solution for free vibration analysis of the beams constructed using functionally graded materials under simply supported boundary conditions. The first order and third order shear deformation theories were used to perform the analysis. Wattanasakulpong et al. [28] presented a study about free vibration behavior of layered beams consisting of FGM based on experimental validation. Pradhan and Chakraverty [29] carried out the free vibration analysis using Euler and Timoshenko beams consisting of FGM under different boundary conditions. In addition, they used Rayleigh-Ritz method to carry out the analysis. Huang and $\mathrm{Li}$ [30] performed a study including the free vibration behavior of beams with FGM in axial direction and the beams have non-uniform cross-section. Liu and Shu [31] presented a study consisting of the free vibration characteristics of beams which having exponential FGM and the beams have a single delamination. Yilmaz and Evran [32] evaluated the numerical and experimental free vibration characteristics of layered short beams consisting of FGM in the axial direction under clamped-free boundary condition. In this study, the natural frequency analysis of layered beams with FGM in thickness direction was investigated using finite element software ANSYS and L9 orthogonal array with three control factors and three levels of each control factor.

\section{MATERIALS AND METHODS}

Numerical analyses were performed using two type materials such as Ti-6Al-4V as metal and $\mathrm{ZrO}_{2}$ as ceramic. Different percent volume fractions of these materials were used to detect the mechanical properties of the layers. The material properties of the Ti-6Al-4V and $\mathrm{ZrO}_{2}$ are tabulated in Table 1 . Poisson's ratio value of each material was used as constant and was taken as 0.3 value.

Table 1. Mechanical properties of Ti-6Al-4V and $\mathrm{ZrO}_{2}$ [33]

\begin{tabular}{ccccc}
\hline Properties & \multirow{2}{*}{ Symbol } & Unit & \multicolumn{2}{c}{ Materials } \\
\cline { 4 - 5 } & & $\mathrm{GPa}$ & Ti-6Al-4V & ZrO $_{2}$ \\
Young's Modulus & $\rho$ & $\mathrm{kg} / \mathrm{m}^{3}$ & 105.7 & 151.0 \\
Density & & 4429.0 & 3000.0 \\
\hline
\end{tabular}

The numerical analyses were conducted to evaluate the influence of control factors such as Layer 1, Layer 2 and Layer 3 on the natural frequency for first mode. Analyses are carried out using L9 orthogonal array design with three control factors and three levels of each control factor. The control factors and their levels were tabulated in Table 2. 
Table 2. Control factors and their levels

\begin{tabular}{cccc}
\hline \multirow{2}{*}{ Control Factors } & \multicolumn{3}{c}{ Levels } \\
\cline { 2 - 4 } Layer1 (L1) & Level 1 & Level 2 & Level 3 \\
Layer2 (L2) & $10 \% \mathrm{ZrO}_{2}-90 \% \mathrm{Ti}-6 \mathrm{Al}-4 \mathrm{~V}$ & $20 \% \mathrm{ZrO}_{2}-80 \% \mathrm{Ti}-6 \mathrm{Al}-4 \mathrm{~V}$ & $30 \% \mathrm{ZrO}_{2}-70 \% \mathrm{Ti}-6 \mathrm{Al}-4 \mathrm{~V}$ \\
Layer3 (L3) & $70 \% \mathrm{ZrO}_{2}-60 \% \mathrm{Ti}-6 \mathrm{Al}-4 \mathrm{~V}$ & $50 \% \mathrm{ZrO}_{2}-50 \% \mathrm{Ti}-6 \mathrm{Al}-4 \mathrm{~V}$ & $60 \% \mathrm{ZrO}_{2}-40 \% \mathrm{Ti}-6 \mathrm{Al}-4 \mathrm{~V}$ \\
\hline
\end{tabular}

It can see from Table 2 that mechanical properties of the layers made of Ti-6Al-4V and $\mathrm{ZrO}_{2}$ materials are selected as control factors. The layers consist of different volume fraction of the Ti-6Al-4V and $\mathrm{ZrO}_{2}$ materials with varying from $90 \%$ to $10 \%$, based on increasing or decreasing of $\% 10$. L1 of the beam was assumed to be metal-rich, whereas L3 was considered to be ceramic-rich. The mechanical properties of the layers were observed based on a simple rule of mixture of composite materials. The effective material properties $P_{\text {ef }}$ of the beam layers can be determined using Equation 1 [34],

$$
P_{e f}=\sum_{j=1} P_{j} V_{f_{j}}
$$

in which, $P_{j}$ and $V_{f j}$ present the mechanical properties and volume fraction of the constituent material $j$ respectively. The sum of the volume fractions of all the constituent materials is equivalent to one as illustrated in Equation 2 [34].

$$
\sum_{j=1} V_{f_{j}}=1
$$

According to a simple rule of mixture of composite materials, the increasing of the Ti-6Al-4V material in the layers decreases Young's Modulus of the layers, whereas the increasing of the $\mathrm{ZrO}_{2}$ material decreases the density of the layers. Nine numerical analyses were performed based on Taguchi method and S/N ratio values of the results obtained were calculated using Minitab R15 statistical software according to larger is better characteristic. The quality characteristic "Larger is better" is given in Equation 3 [37].

$$
(S / N)_{H B}=-10 \cdot \log \left(n^{-1} \sum_{i=1}^{n}\left(y_{i}^{2}\right)^{-1}\right)
$$

in which, $\mathrm{n}$ express number of analysis in a trial and yi represents ith data studied.

\section{FINITE ELEMENT ANALYSIS}

The layered functionally graded beams were analyzed using finite element software called ANSYS V13 Mechanical APDL. The layers were arranged in thickness direction. L1, L2 and L3 are considered as top layer, middle layer and bottom layer respectively. Mechanical properties and positions of the layers and boundary condition for the layered functionally graded beams were used as main factors in order to evaluate numerical analyses results. Nine numerical analyses based on L9 orthogonal array were performed under clamped-free (C-F) boundary condition. In the modelling, SOLID186 solid element was used. This element is a higher order three dimensional 20-node structural solid element and shows quadratic displacement behavior. In addition, this element is described as twenty nodes with 3 degrees of freedom (DF) per node: translations for the nodal $\mathrm{x}, \mathrm{y}$, and $\mathrm{z}$ directions and this element was used in another study [36]. More information for this element can be provided using help menu of ANSYS software. In the analyses, problem dimensionality is used as three dimensional. Degrees of freedom were taken as UX, UY and UZ. Block Lanczos are selected as mode extraction method. Globally 
assembled matrix is used as symmetric. Hex-Mapped are selected for volume mesh operations and 0.01 value are taken as element edge length. Length in $\mathrm{z}$ direction of the layered functionally graded beams is considered as $1.2 \mathrm{~m}$. Cross section base in $\mathrm{x}$ direction and height in y direction of each layer are assumed as $0.12 \mathrm{~m}$ and $0.04 \mathrm{~m}$ respectively. Therefore the layered functionally graded beams were considered as square cross section. The layered functionally graded beams in thickness direction under C-F boundary condition are showed in Figure 1.

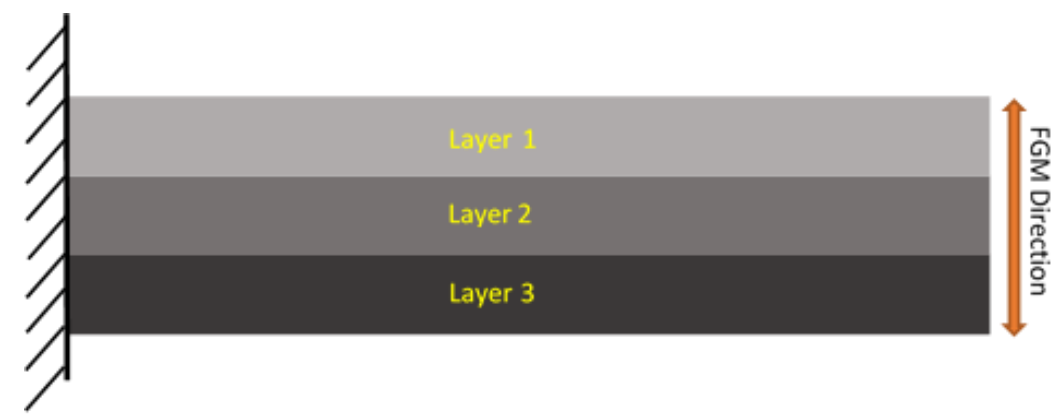

Figure 1. The layered functionally graded beams with C-F boundary condition

\section{NUMERICAL RESULTS AND DISCUSSIONS}

Analyses were performed based on natural frequency for first mode of the layered beams consisting of functionally graded materials. Layer arrangements of the beams were conducted according to L9 orthogonal array. Numerical results of the nine different layered functionally graded beam types were carried out according to finite element method. S/N ratio values of numerical results obtained were calculated using Minitab R15 software according to Equation 3. The numerical results and their S/N ratios values are illustrated in Table 3 .

Table 3. Numerical results and their $\mathrm{S} / \mathrm{N}$ ratio values

\begin{tabular}{|c|c|c|c|c|c|}
\hline \multirow[b]{2}{*}{ Runs } & \multicolumn{3}{|c|}{ Control Factors } & \multicolumn{2}{|c|}{ Results } \\
\hline & L1 & $\mathbf{L} 2$ & $\mathbf{L 3}$ & $\begin{array}{c}\text { Natural } \\
\text { Frequency } \\
\omega(\mathrm{Hz})\end{array}$ & $\begin{array}{c}S / N \\
\text { ratios } \\
\eta(d B)\end{array}$ \\
\hline 1 & $10 \% \mathrm{ZrO}_{2}-90 \% \mathrm{Ti}-6 \mathrm{Al}-4 \mathrm{~V}$ & $40 \% \mathrm{ZrO}_{2}-60 \% \mathrm{Ti}-6 \mathrm{Al}-4 \mathrm{~V}$ & $70 \% \mathrm{ZrO}_{2}-30 \% \mathrm{Ti}-6 \mathrm{Al}-4 \mathrm{~V}$ & 75.7478 & 37.5874 \\
\hline 2 & $10 \% \mathrm{ZrO}_{2}-90 \% \mathrm{Ti}-6 \mathrm{Al}-4 \mathrm{~V}$ & $50 \% \mathrm{ZrO}_{2}-50 \%$ Ti-6Al-4V & $80 \% \mathrm{ZrO}_{2}-20 \%$ Ti-6Al-4V & 77.3436 & 37.7685 \\
\hline 3 & $10 \% \mathrm{ZrO}_{2}-90 \% \mathrm{Ti}-6 \mathrm{Al}-4 \mathrm{~V}$ & $60 \% \mathrm{ZrO}_{2}-40 \% \mathrm{Ti}-6 \mathrm{Al}-4 \mathrm{~V}$ & $90 \% \mathrm{ZrO}_{2}-10 \%$ Ti-6Al-4V & 78.9769 & 37.9500 \\
\hline 4 & $20 \% \mathrm{ZrO}_{2}-80 \% \mathrm{Ti}-6 \mathrm{Al}-4 \mathrm{~V}$ & $40 \% \mathrm{ZrO}_{2}-60 \% \mathrm{Ti}-6 \mathrm{Al}-4 \mathrm{~V}$ & $80 \% \mathrm{ZrO}_{2}-20 \%$ Ti-6Al-4V & 77.9023 & 37.8310 \\
\hline 5 & $20 \% \mathrm{ZrO}_{2}-80 \% \mathrm{Ti}-6 \mathrm{Al}-4 \mathrm{~V}$ & $50 \% \mathrm{ZrO}_{2}-50 \%$ Ti-6Al-4V & $90 \% \mathrm{ZrO}_{2}-10 \% \mathrm{Ti}-6 \mathrm{Al}-4 \mathrm{~V}$ & 79.6981 & 38.0290 \\
\hline 6 & $20 \% \mathrm{ZrO}_{2}-80 \% \mathrm{Ti}-6 \mathrm{Al}-4 \mathrm{~V}$ & $60 \% \mathrm{ZrO}_{2}-40 \% \mathrm{Ti}-6 \mathrm{Al}-4 \mathrm{~V}$ & $70 \% \mathrm{ZrO}_{2}-30 \% \mathrm{Ti}-6 \mathrm{Al}-4 \mathrm{~V}$ & 78.0782 & 37.8506 \\
\hline 7 & $30 \% \mathrm{ZrO}_{2}-70 \% \mathrm{Ti}-6 \mathrm{Al}-4 \mathrm{~V}$ & $40 \% \mathrm{ZrO}_{2}-60 \% \mathrm{Ti}-6 \mathrm{Al}-4 \mathrm{~V}$ & $90 \% \mathrm{ZrO}_{2}-10 \%$ Ti-6Al-4V & 79.8415 & 38.0446 \\
\hline 8 & $30 \% \mathrm{ZrO}_{2}-70 \%$ Ti-6Al-4V & $50 \% \mathrm{ZrO}_{2}-50 \%$ Ti-6Al-4V & $70 \% \mathrm{ZrO}_{2}-30 \% \mathrm{Ti}-6 \mathrm{Al}-4 \mathrm{~V}$ & 78.7561 & 37.9257 \\
\hline 9 & $30 \% \mathrm{ZrO}_{2}-70 \%$ Ti-6Al-4V & $\begin{array}{l}60 \% \mathrm{ZrO}_{2}-40 \% \text { Ti- } 6 \mathrm{Al}-4 \mathrm{~V} \\
\text { Overall Mean }\end{array}$ & $80 \% \mathrm{ZrO}_{2}-20 \%$ Ti-6Al-4V & $\begin{array}{l}80.4564 \\
78.5334\end{array}$ & 38.1112 \\
\hline
\end{tabular}

\subsection{Optimum Layers and Their Effects}

In order to see the influences and optimum levels of the layers on the natural frequency for first mode, the results obtained using finite element software ANSYS were conducted using L9 orthogonal array. The average results and their $\mathrm{S} / \mathrm{N}$ ratio values for each control factor at level 1,2 and 3 for raw values were given in Table 4. 
Table 4. Response table

\begin{tabular}{ccccccc}
\hline \multirow{2}{*}{ Level } & \multicolumn{3}{c}{ Means, $\boldsymbol{\omega}(\mathbf{H z})$} & & \multicolumn{3}{c}{ S/N Ratios, $\boldsymbol{\eta}(\mathbf{d B})$} \\
\cline { 2 - 7 } & $\mathbf{L 1}$ & $\mathbf{L 2}$ & $\mathbf{L 3}$ & $\mathbf{L 1}$ & $\mathbf{L 2}$ & $\mathbf{L 3}$ \\
1 & 77.36 & 77.83 & 77.53 & 37.77 & 37.82 & 37.79 \\
2 & 78.56 & 78.60 & 78.57 & 37.9 & 37.91 & 37.90 \\
3 & 79.68 & 79.17 & 79.51 & 38.03 & 37.97 & 38.01 \\
Delta & 2.33 & 1.34 & 1.98 & 0.26 & 0.15 & 0.22 \\
Rank & 1 & 3 & 2 & 1 & 3 & 2 \\
\hline
\end{tabular}

According to Table 4, the natural frequency for first mode increases with the increase of the layer levels. Optimum layer levels were obtained at third level of layers. The layered functionally graded beam with optimum layer levels provide maximum value of natural frequency for first mode. In addition, it is seen from delta and rank values that L1 has highest effect on the natural frequency for first mode and is followed by L3 and L2 in order that.

\subsection{Analysis of Variance for First Mode Natural Frequency}

In order to detect the significant layers and their percent contributions on natural frequency for first mode of the layered functionally graded beams, Analysis of Variance (ANOVA) for raw data was used. The ANOVA results observed for $\mathrm{R}-\mathrm{Sq}=99.59 \%$ and $\mathrm{R}-\mathrm{Sq}(\mathrm{adj})=98.36 \%$ were presented in Table 5 .

Table 5. ANOVA results for first mode natural frequencies

\begin{tabular}{ccccccc}
\hline Source & DF & Seq SS & Variance & F & P & \% Contribution \\
\hline L1 & 2 & 8.1364 & 4.0682 & 118.4900 & 0.0080 & 48.4523 \\
L2 & 2 & 2.7128 & 1.3564 & 39.5100 & 0.0250 & 16.1547 \\
L3 & 2 & 5.8747 & 2.9374 & 85.5500 & 0.0120 & 34.9839 \\
Error & 2 & 0.0687 & 0.0343 & & & 0.4091 \\
Total & 8 & 16.7926 & & & & \\
\hline
\end{tabular}

DF, Seq SS, F and P refer to degree of freedom, sum of squares, F test statistic and P-value, respectively. Table 5 shows that the most effective parameters on the natural frequency for first mode were obtained for L1 with $48.4523 \%$, L3 with $34.9839 \%$ and L2 with $16.1547 \%$ respectively. All layers have significant influence on the natural frequency for first mode according to the $95 \%$ reliability interval since $\mathrm{p}$ value is smaller than 0.05 value. In addition, $\mathrm{L} 1$ has the greatest effects on responses is followed by L3 and L2 in order.

\subsection{Estimation of the Optimized Result}

The optimum natural frequency for first mode of the layered functionally graded beams is predicted using the optimal levels of significant layers such as L1, L2 and L3. The estimated mean of the first mode natural frequency $\left(\mu_{\omega}\right)$ can be carried out using Equation 4 [35].

$$
\mu_{\omega}=\bar{T}_{\omega}+\left(\overline{L 1}_{3}-\bar{T}_{\omega}\right)+\left(\overline{L 2}_{3}-\bar{T}_{\omega}\right)+\left(\overline{L 3}_{3}-\bar{T}_{\omega}\right)
$$

in which, $\bar{T}_{\omega}$ refers the average mean of natural frequency for first mode in Table 3 is taken from Table 3 as $78.5334 \mathrm{~Hz} \overline{L 1}_{3}, \overline{L 2}_{3}$ and $\overline{L 3}_{3}$ express to average values of natural frequencies for first mode according to third level of the layers and so $79.68 \mathrm{~Hz}, 79.17 \mathrm{~Hz}$ and $79.51 \mathrm{~Hz}$ are taken from Table 4 respectively. According to Equation 4, $\mu_{\omega}$ is calculated as $81.2932 \mathrm{~Hz}$ The $95 \%$ confidence intervals (CI) of confirmation numerical analysis $\left(\mathrm{CI}_{\mathrm{NCA}}\right)$ is carried out based on Equation 5 [37]. 


$$
C I_{\mathrm{NCA}}=\left(F_{\alpha ; 1 ; n_{2}} V_{\text {error }}\left[\frac{1}{n_{e f f}}+\frac{1}{R}\right]\right)^{1 / 2}
$$

where, $\alpha$ is significance level is used as 0.05 value. $n_{2}$ refers to error value of DF (degree of freedom) is used as 2 value from Table 5 and so $\mathrm{F}_{0.05 ; 1: 2}=18.513$ is determined from the list with $\mathrm{F}$ values [35]. $\mathrm{V}_{\text {error }}$ is error value of the variance as shown in Table 5 and is used as 0.0343 . $\mathrm{R}$ is number of replications for confirmation analysis and is used as $1 . n_{\text {eff }}$ is effective number of replications and is calculated as [37],

$$
n_{e f f}=\frac{N}{\left[1+T_{D F}\right]}
$$

in which, $\mathrm{N}$ refers to total number of the numerical natural frequency analyses as shown in Table 3 and is taken as 9. $\mathrm{T}_{\mathrm{DF}}$ is total number of $\mathrm{DF}$ for significant layers as given in Table 5 according to $\mathrm{p}<0.05$ value and is used as 6. According to Equation 6, $\mathrm{n}_{\mathrm{eff}}$ is calculated as 1.2857. Thus $\mathrm{CI}_{\mathrm{NCA}}$ is calculated as 1.0625 . The predicted optimum value of natural frequency for first mode based on $95 \% \mathrm{CI}$ is given by the expression [37],

$$
\left(\mu_{\omega}-\mathrm{CI}_{\mathrm{NCA}}\right)<\mu_{\omega}<\left(\mu_{\omega}+\mathrm{CI}_{\mathrm{NCA}}\right)
$$

The numerical and predicted results of the first mode frequency calculated using the layered functionally

\begin{tabular}{|c|c|c|c|}
\hline \multirow{2}{*}{ Beam with optimum layers } & \multicolumn{2}{|c|}{ Natural Frequencies for First Mode } & \multirow{2}{*}{$\begin{array}{l}\text { Predicted CI at 95\% } \\
\text { Confidence Level }\end{array}$} \\
\hline & ANSYS Result & Predicted Result & \\
\hline & $81.5876 \mathrm{~Hz}$ & $81.2932 \mathrm{~Hz}$ & $80.2307<\mu_{\omega}<82.3557$ \\
\hline $\mathrm{L}_{3}-\mathrm{L}$ & $38.2325 \mathrm{~dB}$ & $38.2011 \mathrm{~dB}$ & $38.0868<\mu_{\mathrm{dB}}<38.3139$ \\
\hline
\end{tabular}
graded beam with optimum layers under C-F boundary condition are given in Table 6.

Table 6. Numerical and predicted results

\subsection{Influences of Boundary Conditions}

In order to investigate the effects of the boundary conditions such as C-F and C-C, natural frequencies of the layered functionally graded beams which having optimum layer levels were analyzed under both boundary conditions using finite element software ANSYS V13 Mechanical APDL. C-F boundary condition were considered as $\mathrm{UX}=\mathrm{UY}=\mathrm{YZ}=$ Fixed for left end and $\mathrm{UX}=\mathrm{UY}=\mathrm{YZ}=$ Free for right end. $\mathrm{C}$ $\mathrm{C}$ boundary condition were also taken as $\mathrm{UX}=\mathrm{UY}=\mathrm{YZ}=$ Fixed for both ends. The results obtained were tabulated in Table 7.

Table 7. First four mode frequencies for C-F and C-C boundary conditions

\begin{tabular}{ccccccccc}
\hline \multirow{2}{*}{ B.C. } & \multirow{2}{*}{ Left End } & \multirow{2}{*}{ Right End } & \multicolumn{5}{c}{$\boldsymbol{\omega}(\mathbf{H z})$} \\
\cline { 4 - 8 } & & & 1. Mode & 2. Mode & 3. Mode & 4. Mode & 5. Mode & 6. Mode \\
C-F & $\mathrm{UX}=\mathrm{UY}=\mathrm{YZ}=$ Fixed & $\mathrm{UX}=\mathrm{UY}=\mathrm{YZ}=$ Free & 81.588 & 81.835 & 489.253 & 490.408 & 725.532 & 1271.680 \\
$\mathrm{C}-\mathrm{C}$ & $\mathrm{UX}=\mathrm{UY}=\mathrm{YZ}=$ Fixed & $\mathrm{UX}=\mathrm{UY}=\mathrm{YZ}=$ Fixed & 493.072 & 494.028 & 1264.760 & 1266.070 & 1453.600 & 2288.350 \\
\hline
\end{tabular}

According to Table 7, the natural frequencies from 1. Mode to 6. Mode increase. Natural frequencies obtained for $\mathrm{C}-\mathrm{C}$ boundary condition are higher than the natural frequencies under C-F boundary condition. Therefore, it can be said that $\mathrm{C}-\mathrm{C}$ boundary condition causes the increase of the natural frequency according to $\mathrm{C}-\mathrm{F}$ boundary condition. Numerical natural frequencies and mode shapes obtained for first six mode under C-F and C-C boundary conditions are illustrated in Figure 2. 


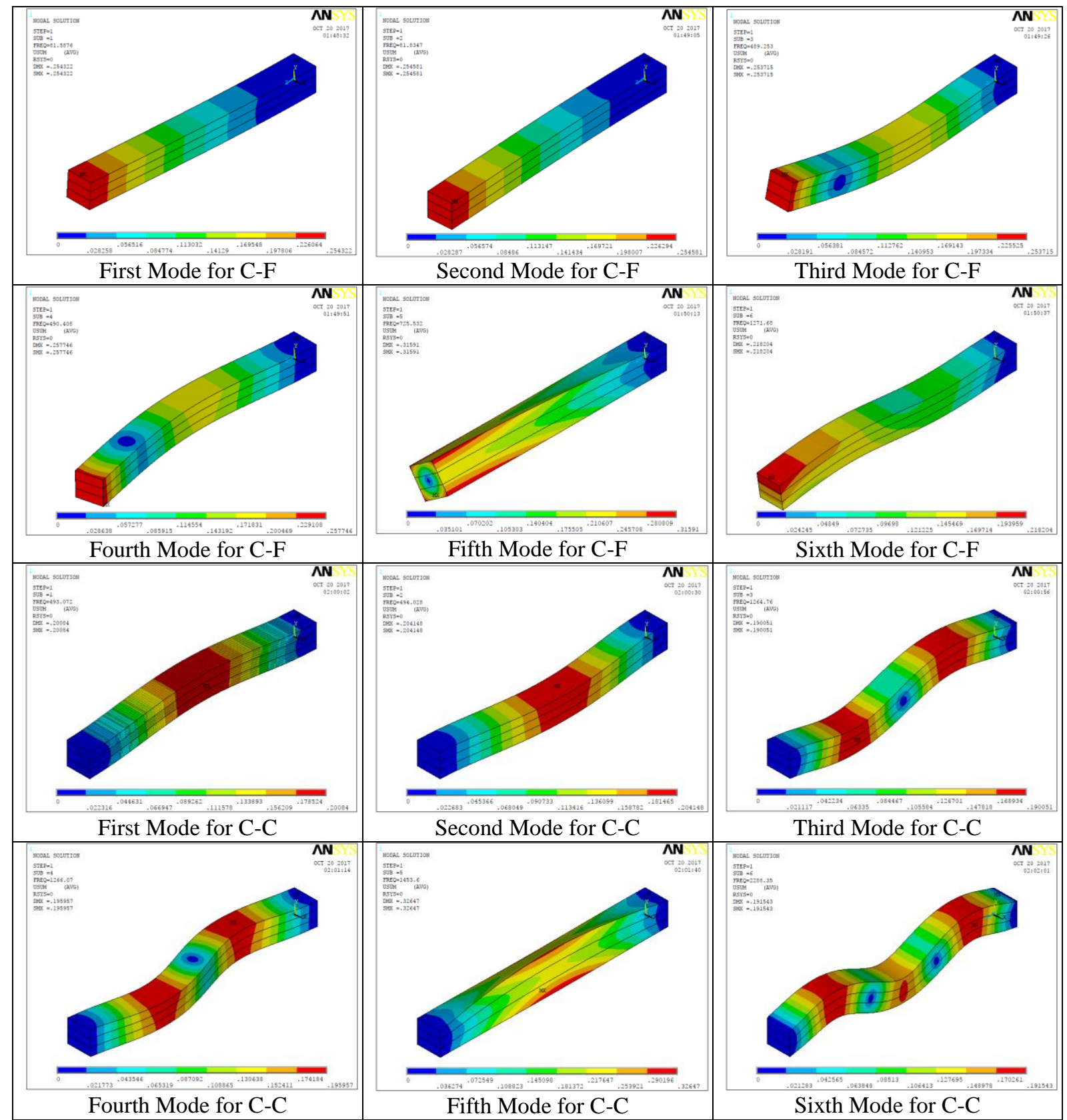

Figure 2. Natural frequency values and mode shapes of layered FG beams with C-F and C-C boundary conditions

\subsection{Comparison of Results}

The numerical results were carried out using finite element software ANSYS. Predicted results were calculated using average value of first mode frequency for each level of each layer and Equation 4. Comparison of the results obtained are given in Table 8 . 
Table 8. Comparison of the numerical and predicted results

\begin{tabular}{|c|c|c|c|c|}
\hline \multirow{2}{*}{ Beam Types } & \multicolumn{2}{|c|}{ Natural Frequency for First Mode, $\omega(\mathrm{Hz})$} & \multirow{2}{*}{ Residual } & \multirow{2}{*}{ Error \% } \\
\hline & ANSYS Results & Predicted Results & & \\
\hline $\mathrm{L} 1_{1}-\mathrm{L} 2_{1}-\mathrm{L} 3{ }_{1}$ & 75.7478 & 75.6532 & 0.0946 & 0.1250 \\
\hline $\mathrm{L} 1_{1}-\mathrm{L} 2_{2}-\mathrm{L} 3_{2}$ & 77.3436 & 77.4632 & -0.1196 & -0.1550 \\
\hline $\mathrm{L}_{1}{ }_{1}-\mathrm{L} 23-\mathrm{L} 33$ & 78.9769 & 78.9732 & 0.0037 & 0.0050 \\
\hline $\mathrm{L} 1_{2}-\mathrm{L} 2{ }_{1}-\mathrm{L} 32$ & 77.9023 & 77.8932 & 0.0091 & 0.0120 \\
\hline $\mathrm{L}_{2}-\mathrm{L} 22_{2}-\mathrm{L} 33$ & 79.6981 & 79.6032 & 0.0949 & 0.1190 \\
\hline $\mathrm{L} 1_{2}-\mathrm{L} 22_{3}-\mathrm{L} 3{ }_{1}$ & 78.0782 & 78.1932 & -0.1150 & -0.1470 \\
\hline $\mathrm{L}_{3}-\mathrm{L} 2{ }_{1}-\mathrm{L} 33$ & 79.8415 & 79.9532 & -0.1117 & -0.1400 \\
\hline $\mathrm{L}_{3}-\mathrm{L} 2_{2}-\mathrm{L} 3{ }_{1}$ & 78.7561 & 78.7432 & 0.0129 & 0.0160 \\
\hline $\mathrm{L}_{3}-\mathrm{L} 23-\mathrm{L} 32$ & 80.4564 & 80.3532 & 0.1032 & 0.1280 \\
\hline
\end{tabular}

Table 8 shows that the difference between ANSYS and predicted results of beam type with $\mathrm{L} 1_{1}-\mathrm{L} 2_{3}-\mathrm{L} 3_{3}$ is very small whereas difference obtained for beam type with $\mathrm{L} 1_{1}-\mathrm{L} 2_{2}-\mathrm{L} 3_{2}$ is found as maximum.

\subsection{Position of Optimum Layers}

In order to analyze the positions of the optimum layers, the layered functionally graded beams made of optimum layers were analyzed under C-F boundary condition. Six different layered functionally graded beams were used. The numerical natural frequencies for first mode obtained for each beam configuration were given in Table 9.

Table 9. Beam configurations with optimum layers

\begin{tabular}{ccccc}
\hline \multirow{2}{*}{$\begin{array}{c}\text { Beam } \\
\text { Types }\end{array}$} & \multicolumn{3}{c}{ Beam Configurations } & ( $(\mathbf{H z})$ \\
\cline { 2 - 5 } Beam 1 & $70 \% \mathrm{Ti}-6 \mathrm{Al}-4 \mathrm{~V}-30 \% \mathrm{ZrO}_{2}$ & $40 \% \mathrm{Ti}-6 \mathrm{Al}-4 \mathrm{~V}-60 \% \mathrm{ZrO}_{2}$ & $10 \% \mathrm{Ti}-6 \mathrm{Al}-4 \mathrm{~V}-90 \% \mathrm{ZrO}_{2}$ & 81.5876 \\
Beam 2 & $70 \% \mathrm{Ti}-6 \mathrm{Al}-4 \mathrm{~V}-30 \% \mathrm{ZrO}_{2}$ & $10 \% \mathrm{Ti}-6 \mathrm{Al}-4 \mathrm{~V}-90 \% \mathrm{ZrO}_{2}$ & $40 \% \mathrm{Ti}-6 \mathrm{Al}-4 \mathrm{~V}-60 \% \mathrm{ZrO}_{2}$ & 79.9238 \\
Beam 3 & $40 \% \mathrm{Ti}-6 \mathrm{Al}-4 \mathrm{~V}-60 \% \mathrm{ZrO}_{2}$ & $70 \% \mathrm{Ti}-6 \mathrm{Al}-4 \mathrm{~V}-30 \% \mathrm{ZrO}_{2}$ & $10 \% \mathrm{Ti}-6 \mathrm{Al}-4 \mathrm{~V}-90 \% \mathrm{ZrO}_{2}$ & 81.8395 \\
Beam 4 & $40 \% \mathrm{Ti}-6 \mathrm{Al}-4 \mathrm{~V}-60 \% \mathrm{ZrO}_{2}$ & $10 \% \mathrm{Ti}-6 \mathrm{Al}-4 \mathrm{~V}-90 \% \mathrm{ZrO}_{2}$ & $70 \% \mathrm{Ti}-6 \mathrm{Al}-4 \mathrm{~V}-30 \% \mathrm{ZrO}_{2}$ & 79.9238 \\
Beam 5 & $10 \% \mathrm{Ti}-6 \mathrm{Al}-4 \mathrm{~V}-90 \% \mathrm{ZrO}_{2}$ & $70 \% \mathrm{Ti}-6 \mathrm{Al}-4 \mathrm{~V}-30 \% \mathrm{ZrO}_{2}$ & $40 \% \mathrm{Ti}-6 \mathrm{Al}-4 \mathrm{~V}-60 \% \mathrm{ZrO}_{2}$ & 81.8395 \\
Beam 6 & $10 \% \mathrm{Ti}-6 \mathrm{Al}-4 \mathrm{~V}-90 \% \mathrm{ZrO}_{2}$ & $40 \% \mathrm{Ti}-6 \mathrm{Al}-4 \mathrm{~V}-60 \% \mathrm{ZrO}_{2}$ & $70 \% \mathrm{Ti}-6 \mathrm{Al}-4 \mathrm{~V}-30 \% \mathrm{ZrO}_{2}$ & 81.5876 \\
\hline
\end{tabular}

Table 9 shows that maximum natural frequency for first mode was obtained using Beam 3 having top layer with $40 \% \mathrm{Ti}-6 \mathrm{Al}-4 \mathrm{~V}-60 \% \mathrm{ZrO}_{2}$, middle layer with $70 \% \mathrm{Ti}-6 \mathrm{Al}-4 \mathrm{~V}-30 \% \mathrm{ZrO}_{2}$ and bottom layer with 10\% Ti-6Al-4V-90\% $\mathrm{ZrO}_{2}$ and Beam 5 having top layer with $10 \%$ Ti-6Al-4V-90\% $\mathrm{ZrO}_{2}$, middle layer with $70 \% \mathrm{Ti}-6 \mathrm{Al}-4 \mathrm{~V}-30 \% \mathrm{ZrO}_{2}$ and bottom layer with $40 \% \mathrm{Ti}-6 \mathrm{Al}-4 \mathrm{~V}-60 \% \mathrm{ZrO}_{2}$. In addition, the numerical natural frequency result for first mode obtained for Beam 1 is equal with result using the Beam 6 configuration. In a similar situation, the result calculated using Beam 2 configuration is equal to value observed using Beam 4 configuration. Thus maximum natural frequency values for first mode were found using top and bottom layers with ceramic-rich and middle layer with metal-rich according to optimum layers. Natural frequencies and mode shapes obtained for beam configurations in Table 9 are shown in Figure 3. 


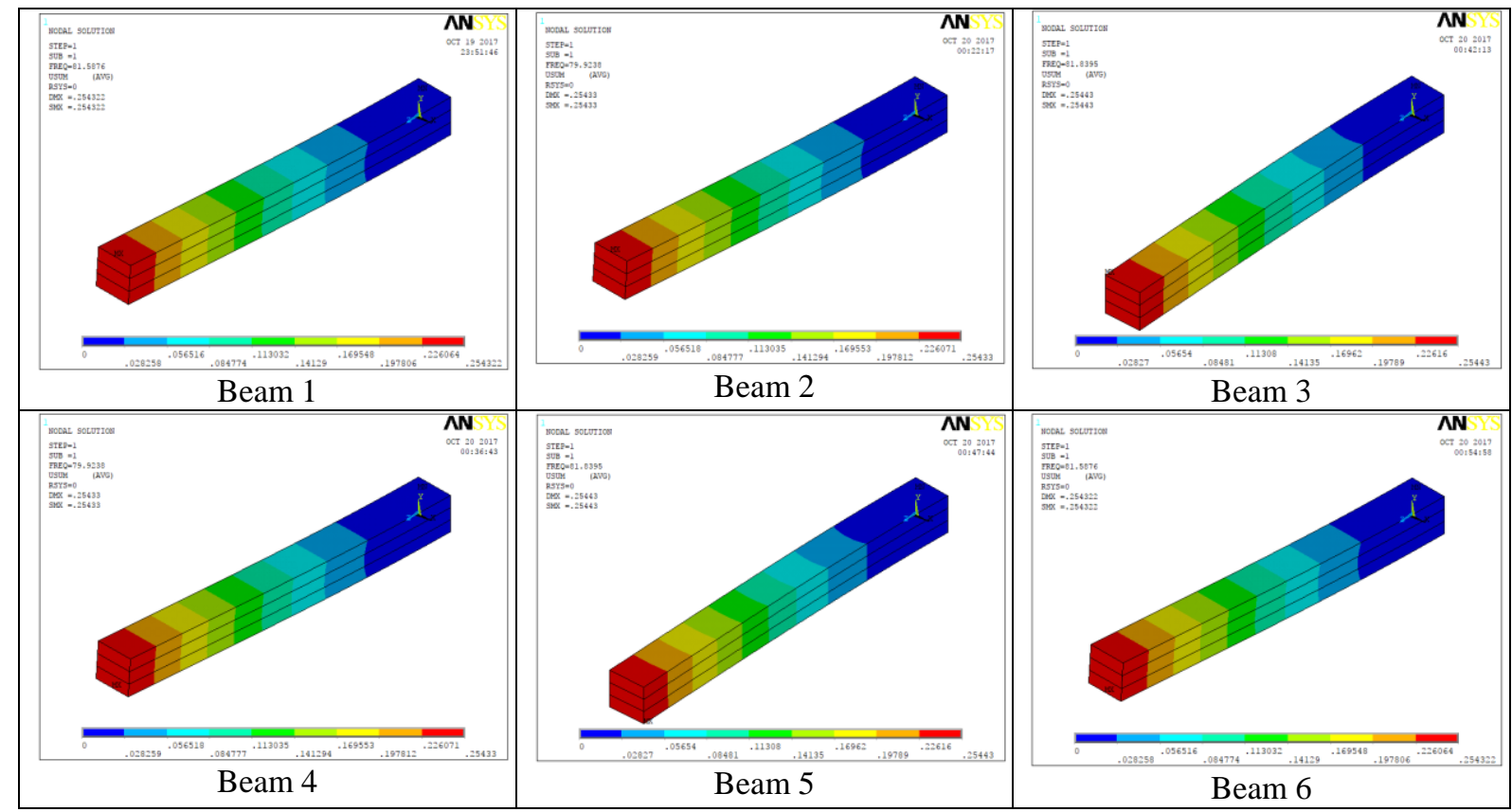

Figure 3. Natural frequency results and mode shapes for first mode of layered FG beams with optimum layers

\section{CONCLUSION}

In this numerical study, the natural frequency of the layered functionally graded beams was investigated under clamped-free boundary condition according to L9 orthogonal array with three control factors and three levels for each layer. In addition, C-F and C-C boundary conditions were used to carry out the effects of the boundary conditions. The layers were considered as control factor and layers arrangements were determined based on L9 orthogonal array. Optimum layers and their levels were used to obtain optimum layer positions for maximum natural frequency. The numerical study reveals the following results:

- Optimum layer levels of the FG beams with C-F boundary condition were obtained using third levels of all layers

- The decreasing of the Ti-6Al-4V material and the increasing of $\mathrm{ZrO}_{2}$ material in layers of the FG beams for C-F boundary condition increase the natural frequencies for first mode.

- The most effective control parameters on the first mode natural frequency of the FG beams with C-F boundary condition were determined as L1 with $48.4523 \%$ contribution, L3 with $34.9839 \%$ contribution and L2 with $16.1547 \%$ contribution respectively.

- All layers have significant influences on the first mode natural frequency of the FG beams with C-F boundary condition because $\mathrm{p}$ value is smaller than 0.05 value.

- An optimized value of the first mode natural frequency of the FG beam with C-F boundary condition at $95 \%$ confidence interval was predicted as $(81.2932 \pm 1.0625) \mathrm{Hz}$ for $80.2307<\mu_{\omega}$ $<82.3557$.

- Maximum first mode natural frequency value of the FG beams with C-F boundary condition according to optimum layers were performed using top and bottom layers with ceramic-rich and middle layer with metal-rich.

- The natural frequencies obtained under C-C boundary condition are higher than C-F boundary condition.

- Natural frequency results for both C-C and C-F boundary conditions increase with increase of the mode values from first mode to sixth mode.

- Layer arrangements of the FG beams with C-F boundary condition play significant role on the natural frequency for first mode directly. 


\section{REFERENCES}

[1] Koizumi M. FGM activities in Japan. Composites Part B: Engineering, 1997; 28:1-4.

[2] Naebe M, Shirvanimoghaddam K. Functionally graded materials: A review of fabrication and properties. Applied Materials Today, 2016; 5:223-245.

[3] Chin ESC. Army focused research team on functionally graded armor composites. Materials Science and Engineering: A, 1999; 259:155-161.

[4] Müller E, Drašar Č, Schilz J, Kaysser WA. Functionally graded materials for sensor and energy applications. Materials Science and Engineering: A, 2003; 362:17-39.

[5] Pompe W, Worch H, Epple $\mathrm{M}$ et al. Functionally graded materials for biomedical applications. Materials Science and Engineering: A, 2003; 362:40-60.

[6] Nomura $\mathrm{T}$, Moriguchi $\mathrm{H}$, Tsuda $\mathrm{K}$ et al. Material design method for the functionally graded cemented carbide tool. International Journal of Refractory Metals and Hard Materials, 1999; $17: 397-404$.

[7] Lee WY, Stinton DP, Berndt CC et al. Concept of functionally graded materials for advanced thermal barrier coating applications. Journal of the American Ceramic Society, 1996; 79:30033012 .

[8] Oh S-Y, Librescu L, Song O. Vibration of turbomachinery rotating blades made-up of functionally graded materials and operating in a high temperature field. Acta Mechanica, 2003; 166:69-87.

[9] Lee JW, Lee JY. Free vibration analysis of functionally graded Bernoulli-Euler beams using an exact transfer matrix expression. International Journal of Mechanical Sciences, 2017; 122:1-17.

[10] Sina SA, Navazi HM, Haddadpour H. An analytical method for free vibration analysis of functionally graded beams. Materials \& Design, 2009; 30:741-747.

[11] Giunta G, Crisafulli D, Belouettar S, Carrera E. Hierarchical theories for the free vibration analysis of functionally graded beams. Composite Structures, 2011; 94:68-74.

[12] Şimşek M. Fundamental frequency analysis of functionally graded beams by using different higherorder beam theories. Nuclear Engineering and Design, 2010; 240:697-705.

[13] Aydogdu M, Taskin V. Free vibration analysis of functionally graded beams with simply supported edges. Materials \& Design, 2007; 28:1651-1656.

[14] Kahya V, Turan M. Finite element model for vibration and buckling of functionally graded beams based on the first-order shear deformation theory. Composites Part B: Engineering, 2017; 109:108115.

[15] Thai H-T, Vo TP. Bending and free vibration of functionally graded beams using various higherorder shear deformation beam theories. International Journal of Mechanical Sciences, 2012; 62:5766.

[16] Alshorbagy AE, Eltaher MA, Mahmoud FF. Free vibration characteristics of a functionally graded beam by finite element method. Applied Mathematical Modelling, 2011; 35:412-425. 
[17] Nguyen T-K, Vo TP, Thai H-T. Static and free vibration of axially loaded functionally graded beams based on the first-order shear deformation theory. Composites Part B: Engineering, 2013; 55:147-157.

[18] Kapuria S, Bhattacharyya M, Kumar AN. Bending and free vibration response of layered functionally graded beams: A theoretical model and its experimental validation. Composite Structures, 2008; 82:390-402.

[19] Li X, Li L, Hu Y et al. Bending, buckling and vibration of axially functionally graded beams based on nonlocal strain gradient theory. Composite Structures, 2017; 165:250-265.

[20] Huang Y, Yang L-E, Luo Q-Z. Free vibration of axially functionally graded Timoshenko beams with non-uniform cross-section. Composites Part B: Engineering, 2013; 45:1493-1498.

[21] Shahba A, Rajasekaran S. Free vibration and stability of tapered Euler-Bernoulli beams made of axially functionally graded materials. Applied Mathematical Modelling, 2012; 36:3094-3111.

[22] Wattanasakulpong N, Ungbhakorn V. Free vibration analysis of functionally graded beams with general elastically end constraints by DTM. World Journal of Mechanics, 2012; 2:297-310.

[23] Demir APC, Oz F. Free Vibration analysis of a functionally graded beam with finite elements method. Vibration Problems ICOVP 2011: the 10th International Conference on Vibration Problems. ICOVP 2011 Supplement; 2011; 37-42.

[24] Demir C, Oz FE. Free vibration analysis of a functionally graded viscoelastic supported beam. Journal of Vibration and Control, 2014; 20:2464-2486.

[25] Anandrao KS, Gupta R, Ramachandran P, Rao GV. Free vibration analysis of functionally graded beams. Defence Science Journal, 2012; 62:139-146.

[26] Kukla S, Rychlewska J. Free vibration analysis of functionally graded beams. Journal of Applied Mathematics and Computational Mechanics, 2013; 12:39-44.

[27] Koochaki GR. Free vibration analysis of functionally graded beams. World Academy of Science, Engineering and Technology, 2011; 514-517.

[28] Wattanasakulpong N, Prusty BG, Kelly DW, Hoffman M. Free vibration analysis of layered functionally graded beams with experimental validation. Materials \& Design (1980-2015), 2012; 36:182-190.

[29] Pradhan K, Chakraverty S. Free vibration of Euler and Timoshenko functionally graded beams by Rayleigh-Ritz method. Composites Part B: Engineering, 2013; 51:175-184.

[30] Huang Y, Li X-F. A new approach for free vibration of axially functionally graded beams with non-uniform cross-section. Journal of sound and vibration, 2010; 329:2291-2303.

[31] Liu Y, Shu D. Free vibration analysis of exponential functionally graded beams with a single delamination. Composites Part B: Engineering, 2014; 59:166-172.

[32] Yilmaz Y, Evran S. Free vibration analysis of axially layered functionally graded short beams using experimental and finite element methods. Science and Engineering of Composite Materials, 2016; 23(4): 453-460. 
[33] Talha M, Singh BN. Static response and free vibration analysis of FGM plates using higher order shear deformation theory. Applied Mathematical Modelling, 2010; 34:3991-4011.

[34] Shen H-S. Functionally graded materials: nonlinear analysis of plates and shells. CRC press: Boca Raton; 2009.

[35] Roy RK. A primer on the Taguchi method. Van Nostrand Reinhold, New York; 1990.

[36] Siddiqui HR, Shivhare V. Free vibration analysis of eccentric and concentric isotropic stiffened plate with orthogonal stiffeners using ANSYS. International Journal of Signal Processing, Image Processing and Pattern Recognition, 2015; 8:271-284.

[37] Ross PJ. Taguchi Techniques for Quality Engineering, 2nd Edition, McGraw-Hill International Book Company, New York; 1996. 